MBIA
p-ISSN 2086-5090, e-ISSN: 2655-8262
Vol. 18, No. 1, April 2019
Peringkat Akreditasi Sinta 5

\title{
Model Pembangunan Daerah 3T: Studi Kasus Daerah Perbatasan Kabupaten Bengkayang
}

\author{
Dokman Marulitua Situmorang \\ Sekolah Tinggi Ilmu Manajemen Shanti Bhuana \\ dokman@shantibhuana.ac.id \\ Rissa Ayustia \\ Sekolah Tinggi Ilmu Manajemen Shanti Bhuana \\ Email: ayustia.rissa@shantibhuana.ac.id
}

\begin{abstract}
Based on the introduction survey did by researcher with one of example confine area is lunar subdistrict Bengkayang Regency. That same of area still has not the public infrastructure and health is not adequate such as serem silimbau village has not electricity, clean water and infrastructure of road is bad. So that we concluded which the problem is coming from the construction some of 3T area, cause the goverment can't see with going deep which sensibility some of 3T area which available border with the neighbour some of countries. This case seen from the border direct areas with Malaysia such us Riau Island and west kalimantan province. Two construction of areas are difference, because many factor, like sosial factor, tradition, custom tradition and geografical. The purpose of research to find out one of true model in $3 \mathrm{~T}$ area development which direct border with the neighbour some of countries, and this model become clue for sides that redated with area goverment and central this research did based on the development survey method (development Research). Accumulition data technigue with purposevi sampling method. The result of research that the $3 \mathrm{~T}$ area construction in kalimantan border specially jagoi babang subdistrict Bengkayang regency, in order to do the construction model based on good infrastructure and health, because the case will influence development area development based on the local learning, tradition, and area culture.
\end{abstract}

Keywords:Development, Outermost, Frontier, Underdeveloped Region

\section{Abstrak}

Berdasarkan survey pendahuluan yang dilakukan oleh peneliti dengan mengambil kecamatan Lumar kabupaten Bengkayang, bahwa masih adanya dibeberapa desa serem silimbau belum teralirnya listrik, air bersih dan infrastruktur jalan yang tidak baik. Maka dapat disimpulkan bahwa Permasalahan yang timbul dalam pembangunan daerah-daerah 3T adalah tidak mampunya pemerintah baik daerah dan pusat melihat secara mendalam permasalahan yang di alami oleh daerah-daerah 3T yang ada berbatasan dengan beberapa Negaranegara tetangga. Hal itu dapat dilihat dari daerah-daerah yang langsung berbatasan dengan Negara Malaysia seperti Kepulauan Riau dan Provinsi Kalimatan Barat. Pembangunan 2 (dua) daerah sangatlah berbeda, karena banyak faktor.Yaitu Faktor Sosial, Tradisi, Adat istiada dan geografis. Tujuan dari penelitian ini adalah untuk menemukan suatu model manajemen yang tepat dalam pembagunan daerah 3T yang mana berbatasan langsung dengan Negara-negara tetangga, dan model ini bisa menjadi masukan bagi pihak-pihak yang terkait baik itu pemerintah daerah dan pusat.Penelitian ini dilakukan melalui survey dengan metode perkembangan (Developmental Research). Teknik pengumpulan data dengan metode purposive sampling. Hasil penelitian bahwa pembanguan daerah 3T di perbatasan kalimantan yang dikhususkan di kecamatan jagoi babang kabupaten Bengkayang, agar perlu dilakukan model pembangunan yang berlandaskan infrastruktur baik umum dan kesehatan, karena hal itu akan mempengaruhi perkembangan dan pertumbuhan pembangunan daerah yang berlandaskan pada kearifan lokal, tradisi, dan budaya daerah tersebut.

Kata Kunci : Pembangunan, Daerah Terluar, Terdepan, Tertinggal

\section{Pendahuluan}

Salah satu yang menjadi agenda nawacita dari Presiden Joko Widodo, yaitu pembangunan Indonesia dilakukan dari pinggiran dengan menguatkan sisi sosial, ekonomi dan pembangunan sumber daya manusia di seluruh wilayah Indonesia, termasuk daerah tertinggal baik yang ada dikepulauan terluar dan daratan. Indonesia memiliki daerah perbatasan yang sangat luas, 
dimana secara letak geografis Indonesia berbatasan dengan beberapa Negara yang lebih maju dari Indonesia, diantaranya Negara Brunei Darusalam, Malaysia, Singapore, Australia, dan beberapa Negara yang sedang berkembang yaitu Thailand, Vietnam, Filipina, selaindari Negara sedang maju dan berkembang Indonesia juga berbetasan dengan beberapa Negara yang ekonominya dibawah indonesia yaitu Timor Leste, Papua Nuigini.

Maka peluang Indonesia yang daerahnya banyak berbatasan dengan beberapa Negara yang lebih baik ekonominya dan lebih maju dari Indonesia sangat bisa menguntungkan daerahdaerah yang berbatasan langsung dengan Negara-negara tersebut.Sehingga perlu diperhatikan dan daimanfaatkan dari peluang dampak berbatasan dari Negara-negara yang lebih maju dari Indonesia. Ada beberapa daerah yang berbatasan langsung dengan Negara-negara lebih maju tersebut, yaitu provinsi Kepulauan Riau yang mana berbatasan langsung dengan Negara Singapura dan Malaysia dan beberapa provinsi Kalimantan yang langsung berbatasan langsung dengan Negara Malaysia.

Namun pada kenyataannya hanya provinsi Kepulauan Riau yang mampu menangkap peluang tersebut, hal itu dapat dilihat dari pertumbuhan ekonomi dan pembangunan yang terjadi didaerah tersebut, contohnya kota Batam dan kota Tanjungpinang, sedangkan provinsiprovinsi yang ada di pulau Kalimantan belum mampu menangkap dan memanfaatkan peluang yang ada. Hal itu dapat dilihat dari masih adanya bebarapa daerah tertinggal di daerah Kalimantan.Demikian juga beberapa daerah yang berbatasan langsung dan tidak langsung dengan Negara-negara lebih maju dan pertumbuhan ekonominya dibawah Negara Indonesia.

Daerah-daerah yang berbatasan langsung dengan Negara-negara lain masih sangat banyak memprihatinkan baik itu yang berhubungan dengan infrastruktur, sumber daya manusia yang kurang memadai, hal itu memjadi perhatian dari pemerintah sekarang ini. Upaya pemerintah dalam membangunan daerah perbatasan maka dikeluarkanlah program pembangunan daerah 3T (Terdepan, Terluar, Tertinggal) pembangunan daerah 3T sudah mulai dilakukan dengan membangunan daerah kawasan perbatasan lintas batas Negara, seperti pembangunan diprovinsi Kalimantan Barat yaitu Entikong, Manga Badan, dan Aruk dimana berbatasan langsung dengan Negara Malaysia.

Berdasarkan survey pendahuluan yang dilakukan oleh peneliti dengan mengambil salah satu daerah yang berbatasan dengan negara Malaysia yang ada di kabupaten Bengkayang yaitu kecamatan Lumar kabupaten Bengkayang, berdasarkan observasi awal bahwa masih adanya dibeberapa desa serem silimbau belum teralirnya listrik, air bersih dan infrastruktur jalan dan infrastruktur umum baik itu sekolah, kesehatan, ketersediaan air bersih dan listrik mempengaruhi pembangunan tersebut. Maka dapat disimpulkan bahwa Permasalahan yang timbul dalam pembangunan daerah-daerah 3T adalah tidak mampunya pemerintah baik daerah dan pusat melihat secara mendalam permasalahan yang dialami oleh daerah-daerah 3T yang ada berbatasan dengan beberapa Negara-negara tetangga. Hal itu dapat dilihat dari daerahdaerah yang langsung berbatasan dengan Negara Malaysia seperti Kepulauan Riau dan Provinsi Kalimatan Barat.Pembangunan 2 (dua) daerah sangatlah berbeda, karena banyak faktor.Yaitu Faktor Sosial, Tradisi, Adat istiada dan geografis. 


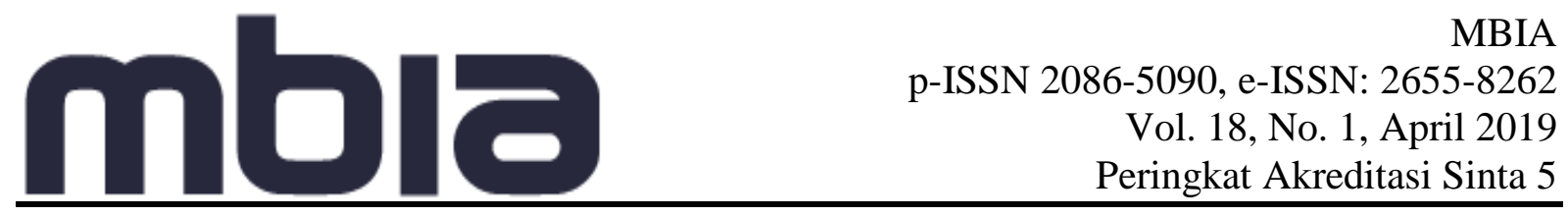

Gambar 1. Kondisi Infrastruktur Jalan di Kecamatan Lumar, Kel. Molo
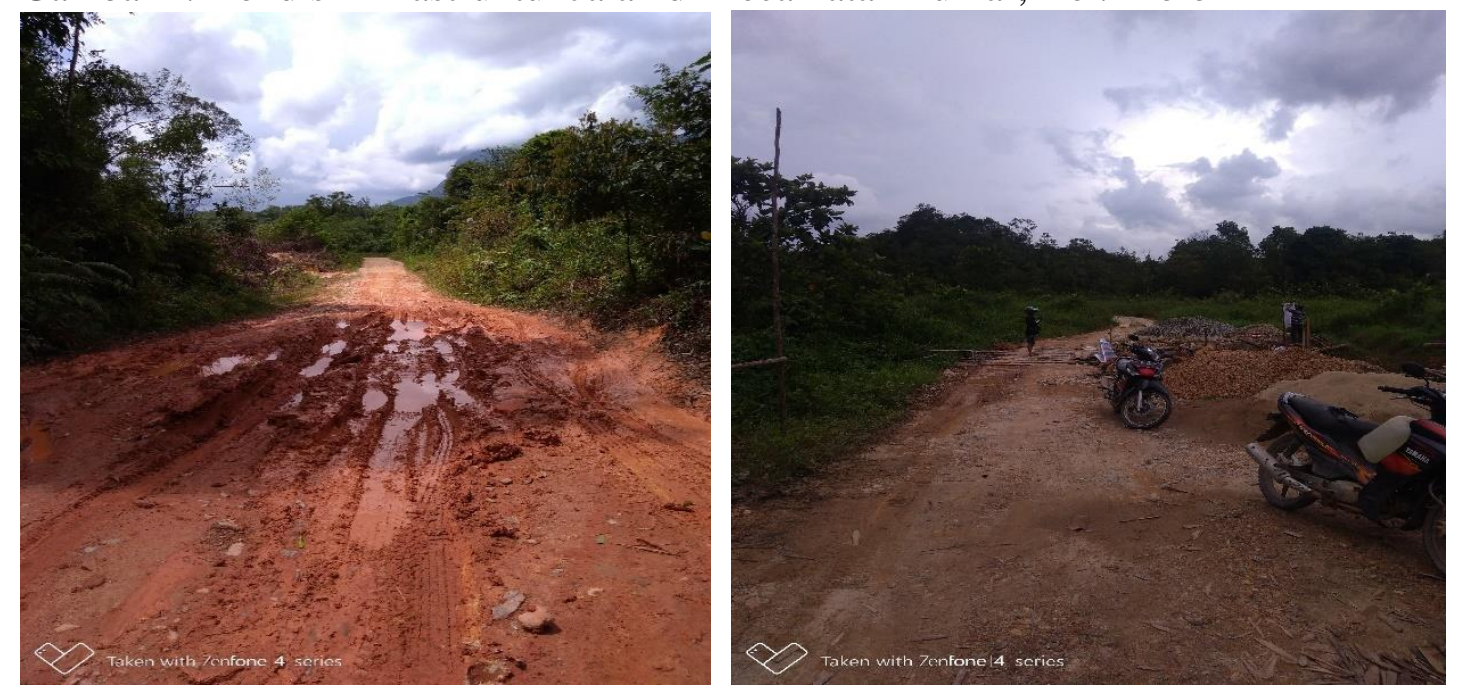

Sumber : Survei Lapangan, 2018

Tujuan dari penelitian ini adalah untuk menemukan suatu model yang tepat dalam pembagunan daerah $3 \mathrm{~T}$ yang mana berbatasan langsung dengan Negara-negara tetangga khususnya Negara Malaysia, dan model ini bisa menjadi masukan bagi pihak-pihak yang terkait baik itu pemerintah daerah dan pusat.

\section{Literature Review}

\subsection{Daerah}

Daerah mempunyai definisi yang berbeda-beda tergantung pada aspek tinjauannya. Dari tinjauan aspek ekonomi, daerah mempunyai tiga definisi, yaitu :

1. Suatu daerah dianggap sebagai ruang di mana kegiatan ekonomi terjadi dan di dalam berbagai pelosok ruang tersebut terdapat sifat-sifat yang sama. Kesamaan sifat-sifat tersebut, antara lain tercermin dari segi pendapatan per kapitanya, sosialbudayanya, geografisnya, dan lain sebagainya. Daerah dalam definisi seperti ini disebut dengan daerah homogeny.

2. Suatu daerah dianggap sebagai suatu "ruang ekonomi" yang dikuasai oleh satu atau beberapa pusat kegiatan ekonomi. Daerah dalam defenisi seperti ini disebut dengan daerah nodal.

3. Suatu daerah adalah suatu "ruang ekonomi" yang berada di bawah satu administrasi tertentu, seperti satu provinsi, kabupaten, kecamatan, dan sebagainya. Jadi, daerah di sini didasarkan atas pembagian administrative suatu Negara. Daerah dalam definisi seperti ini disebut daerah perencanaan atau daerah administrasi. ${ }^{1}$

\subsection{Perencanaan Pembangunan Daerah}

Menurut Mudrajad (2014:81) setidaknya ada 3 (tiga) unsur dasar dari perencanaan pembangunan ekonomi daerah jika dengan hubungan pusat dan daerah :

1. Perencanaan pembangunan ekonomi daerah yang realistik memerlukan pemahaman tentang hubungan antara daerah dengan lingkungan nasional di mana daerah tersebut

\footnotetext{
1 Lincolin Arsyad. 2015. Ekonomi Pembangunan. Cetakan Kedua. Penerbit dan Percetakan UPP STIM YKPN.Yogyakarta.hlm 373-374
} 


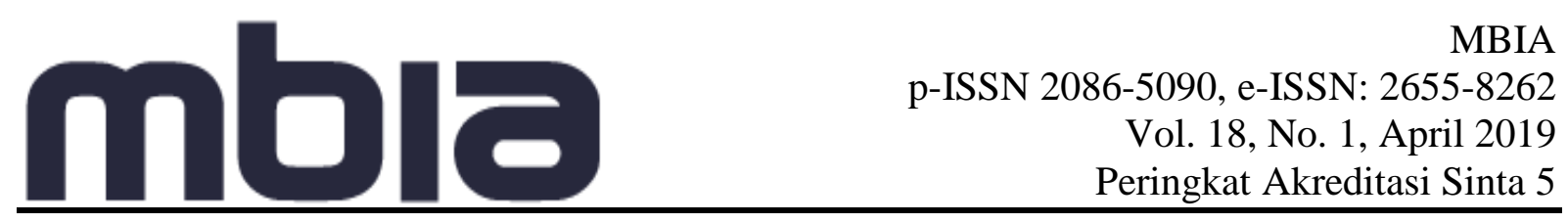

merupakan bagian darinya, keterkaitan secara mendasar antara keduanya, dan konsekuensi akhir dari interaksi tersebut.

2. Sesuatu yang tampaknya baik secara nasional belum tentu baik untuk daerah, dan sebaliknya yang baik bagi daerah belum tentu baik secara nasional.

3. Perangkat kelembagaan yang tersedia untuk pembangunan daerah misalnya, administrasi, proses pengambilan ${ }^{2}$ keputusan, dan otoritas biasanya sangat berbeda pada kedua tingkat tersebut.

4. Menurut Blakely, dalam Mudrajad 2014: 87 Sumber daya perencanaan untuk pembangunan daerah dibagi dalam beberapa lingkungan pembangunan, diantaranya :

5. Lingkungan Fisik Sebagai Sumber Daya Perencanaan\

6. Pemerintah daerah biasanya memperhatikan masalah lingkungan fisik, terutama infrastruktur fisik, yang tentu saja penting bagi dunia usaha dan industri.

7. Lingkungan Regulasi sebagai Sumber Daya Perencanaan

8. Kita semua memahami bahwa insentif dan kebijakan keuangan merupakan input penting bagi proses pembangunan ekonomi.

9. Lingkungan Perilaku Sumber Daya Perencanaan

10. Keputusan yang diambil sektor swasta mengenai ekpansi investasi atau relokasi tidak hanya didasarkan pada data semata.

Menurut Arsyad (1999) sebenarnya konsep pembangunan daerah harus dibedakan dengan pembangunan ekonomi daerah. Pembangunan daerah merupakan upaya terpadu yang menggabungkan beberapa dimensi kebijakan dari seluruh sektor yang ada. Tujuan pembangunan daerah adalah mewujudkan masyarakat yang damai, demokratis, berkeadilan, berdaya saing, maju dan sejahtera. Sedangkan pembangunan ekonomi daerah pelaksanaannya tetap berpegang pada tujuan pembangunan daerah. Jadi pembangunan daerah tidak sematasemata ekonomis semata.

Moeljarto Tjokrowinoto (1993) menjalaskan pengertian dari perencanaan pembangunan sebagai konsep yang menyangkut dua spek yaitu pertama sebagai suatu proses perumusan rencana pembangunan, dan kedua sebagai substansi rencana pembangunan itu sendiri. Proses perumusan rencana pembangunan berkaitan dengan aktivitas bagaimana sebuah perencanaan pembangunan disusun, kapan dan siapa saja pihak-pihak yang terlibat dalam proses penyusunan prencenaan tersebut. Sedangkan substansi rencana pembangunan berbicara mengena apa isi dari rencana pembangunan yang telah disusun, permasalahan pokok dan isuisu strategis yang mendesak untuk diselesaikan dalam pembagunan.

\subsection{Daerah 3 T (Terdepan,Terluar, Tertinggal)}

Perpres RI Nomor 131 Tahun 2015 tentang daerah tertinggal tahun 2015-2019

Pasal 1 yaitu :

1. Daerah tertinggal adalah daerah kabupaten yang wilayah serta masyarakatnya kurang berkembang dibandingkan dengan daerah lain dalam skala nasional.

2. Menteri adalah menteri yang menyelenggarakan urusan pemerintahan di bidang pembangunan tertinggal.

Pasal 2 .

1. Suatu daerah ditetpakan sebagai daerah tertinggal berdasarkan criteria :

a. Perekonomian masyarakat; 


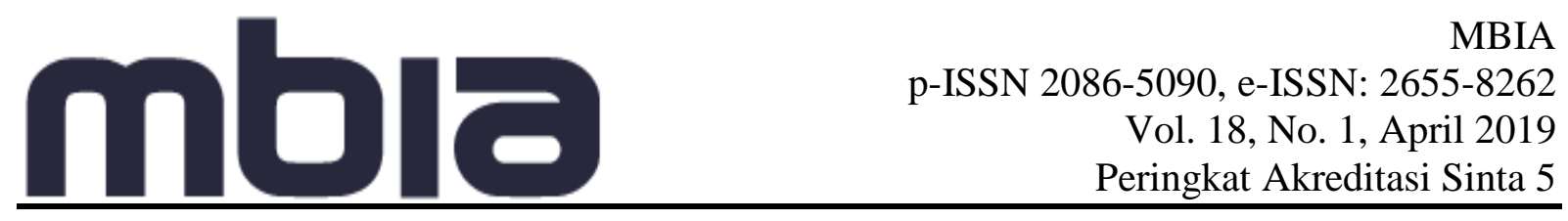
b. Sumber daya manusia;
c. Sarana dan prasarana;
d. Kemampuan keuangan daerah;
e. Aksesibilitas; dan
f. Karakteristik daerah;

Menurut Rohmad Supriyadi strategi pengembangan kawasan perbatasan antara lain :

1. Penuntasan masalah kejelasan batas wilayah kedaulatan (teritorial) dan batas yuridiksi dengan Negara tetangga melalui penetapan batas darat dan laut, (batas laut teritorial, landas kontinen, batas zona ekslisuf) berdasarkan perjanjian internasional dengan Negara tetangga. Strategi ini dijabarkan melalui fokus prioritas.

a. penyelesaian penetapan batas wilayah territorial.

b. Penegasan batas wilayah yuridiksi.

2. Peningkatan pertahanan dan keamanan untuk menjaga kedaulatan dan keutuhan wilayah Negara kesatuan Republik Indonesia (NKRI). Strategi ini dijabarkan melalui fokus prioritas :

a. Peningkatan upaya pertahanan

b. Peningkatan upaya keaman

c. Penegakan hukum.

3. Mempercepat pembangunan melalui pengembangan ekonomi local dengan diciptakan keterkaitan pengembangan wilayah antara kotan utama dikawasan perbatasan (PKSN) dengan desa-desa disekitarnya dan Negara tetangga. Strategi ini dijabarkan melalui fokus prioritas :

a. Pengembangan ekonomi lokal.

b. Peningkatan ekonomi daerah berbasis sektor unggulan,

c. Penyediaan dan peningkatan fasilitas perekonomian,

d. Pengembangan kesempatan kerja,

4. Penyediaan sarana dan prasarana wilayah untuk mendukung keberlanjutan percepatan pembangunan kawasan perbatasan. Strategi ini dijabarkan melalui fokus prioritas :

a. Peningkatan aksesibilitas melalui penyediaan infrastruktur transportasi,

b. Penyediaan sarana dan prasrana telekomunikasi dan informasi,

c. Penyediaan dan peningkatan orang listrik.

5. Mengembangkan kualitas sumber daya manusia melalui peningkatan kualitas pelayanan public diwilayah-wilayah yang berbatasan langsunng dengan Negara tetangga termasuk di pulau-pulau kecil terluar. Strategi ini dijabarkan melalui fokus prioritas ;

a. Peningkatan pelayanan kesehatan,

b. Peningkatan pelayanan pendidikan,

c. Penyediaan pemukiman dan perumahan.

6. Meningkatkan pelestarian kawasan lindung untuk menunjang keberlajutan pembangunan yang berwawasan lingkungan. Strategi ini dijabarkan melalui fokus prioritas ;

a. Peningkatan kegiatan rehabilitasi lingkungan hidup,

b. Pemeliharaan lingkungan hidup.

7. Membentuk dan mengembangkan kapasitas kelembagaan pemerintahan dalam pengelolaan kawasan perbatasan. Strategi ini dijabarkan melalui fokus prioritas;

a. Penyediaan sarana penunjang pemerintah,

b. Peningkatan kapasitas aparatur pemerintah, 


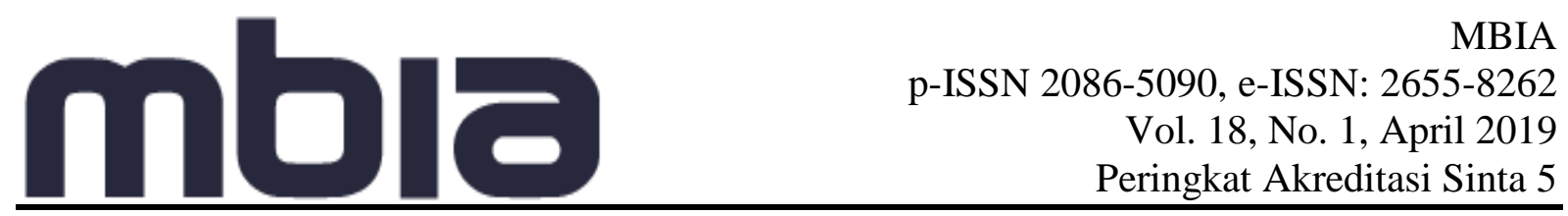

c. Peningkatan kordinasi dan kerjasama.

Terbatasnya teori-teori pendukung tentang daerah 3T (Terdepan, Terluar, Tertinggal) maka dalam hal peneliti mengamnbil suatu kesimpulan baik itu berdasrkan temuan-temuan fenomena dan permasalahan yang didapat dari hasil survei dan observasi daerah tujuan penelitian. Daerah merupakan suatu wilayah yang bisa dikatakan bahwa kawasannya dan batasan wilayahnya sudah ditentukan oleh suatu pemerintah sesuai dengan ketentuan yang berlaku baik itu berupa peraturan daerah atau perautaran pemerintah pusat. Daerah 3T (Terdepan, Terluar, Tertinggal) merupakan daerah yang memiliki kondisi wilayah yang berbatasan langsung dengan negara lain, dan daerah tersebut memiliki karakteristik kurang lengkapnya sarana dan prasarana dari infrastruktur baik itu infrastruktur umum dan kesehatan. Daerah 3T identik dengan perbatasan, pertumbuhan ekonomi yang rendah namun ada beberapa faktor-faktor yang menjadikan daerah itu disebut daerah 3T, yaitu :

1. Tidak memiliki infrastruktur umum seperti jalan aspal atau beton yang baik, listrik dan air bersih.

2. Tidak memiliki kelengkapan pelayanan kesehatan baik itu puskesmas dan rumah sakit umum.

3. Memiliki batas wilayah yang langsung berbatasan dengan negara lain.

4. Memiliki transaksi jual dan beli barang dengan 2 mata uang yang saling berbatasan.

\section{Metodologi Penelitian}

Penelitian ini dilakukan melalui survey dengan metode perkembangan (Developmental Research). Menurut Akker. V. D dan Plomp (1993) metode perkembangan (Developmental Research) adalah mendeskripsikan penelitian pengembangan berdasarkan dua tujuan yakni sebagai pengembangan prototype produk dan sebagai perumusan saran-saran metodologis untuk pendesainan dan evaluasi prototype produk tersebut.

Gambar 2. Model Tahap Penelitian Developmental Research

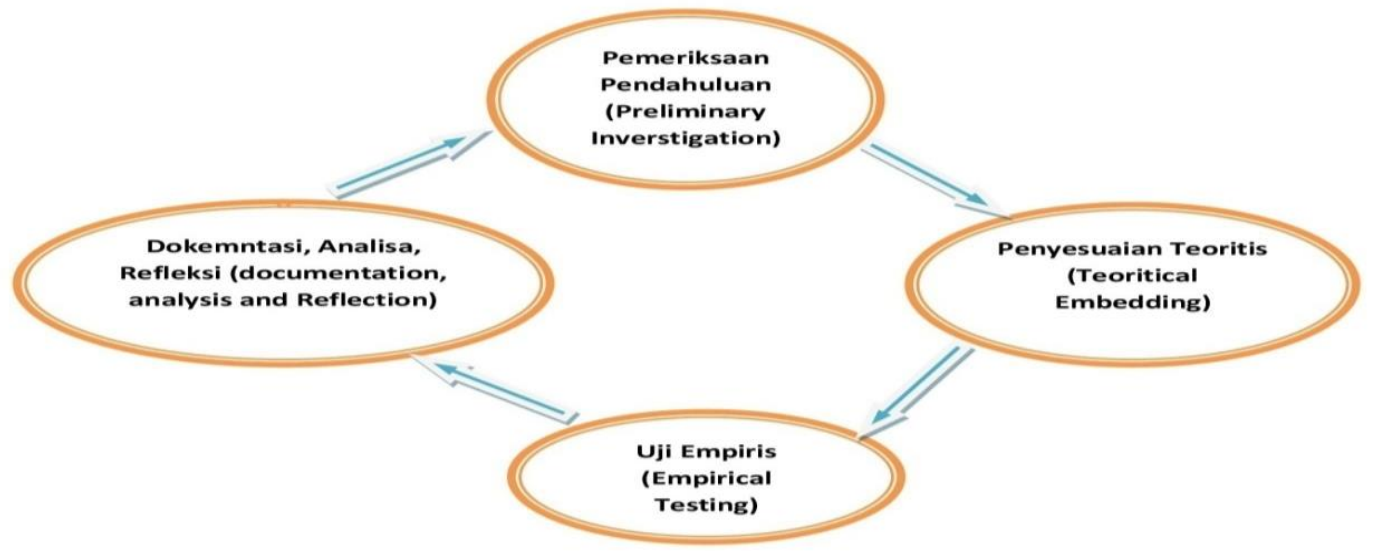

Guna mendapatkan informasi secara umum tentang keadaan daerah-daerah yang potensial untuk dikembangkan, maka penelitian ini banyak memanfaatkan data primer yang didapatkan melalui survei. Data sekunder hanya bersifat sebagai pendukung. Studi ini dilakukan di daerah Kabupaten Bengkayang provinsi Kalimantan Barat dengan pemilihan lokasi dilakukan secara cluster di daerah perbatasan. 


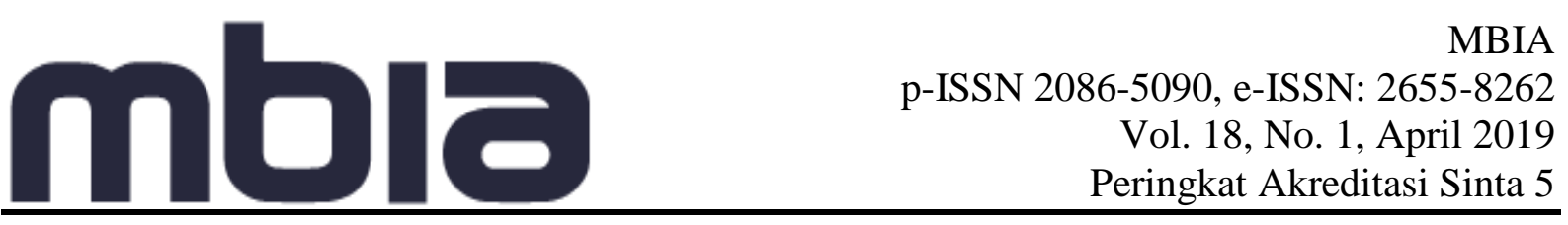

Teknik pengumpulan data dengan metode purposive sampling. Menurut Sugiyono (2012: 122), purposive sampling adalah teknik penentuan sampel dengan pertimbangan tertentu. Metode ini digunakan dengan pertimbangan bahwa letak lokasi penelitian yang berpencaran, karakteristik masyarakat sebagai objek penelitian yang beragam, dan informasi yang diperlukan dapat diperoleh melalui kuesioner dan wawancara secara mendalam. Variabel yang diukur dalam studi ini adalah variabel yang diperlukan untuk pembangunan daerah $3 \mathrm{~T}$.

Penelitian ini memerlukan data primer. Untuk data primer pengumpulan data dilakukan dengan metode Rapid Rural Appraisal (RRA), yaitu suatu pendekatan partisipatif untuk mendapatkan data/informasi dan penilaian (assesment) secara umum di lapangan dalam waktu yang relatif pendek. Kelebihan pendekatan ini adalah penelitian bisa mencakup daerah yang lebih luas dalam waktu relatif singkat untuk mendapatkan informasi yang luas secara umum. Pengumpulan informasi dan data dilakukan secara fleksibel, tidak terikat secara kaku dengan kuesioner. Dalam metode RRA ini informasi yang dikumpulkan terbatas pada informasi dan yang dibutuhkan sesuai dengan tujuan penelitian, namun dilakukan dengan lebih mendalam dengan menelusuri sumber informasi sehingga didapatkan informasi yang lengkap tentang sesuatu hal. Kuesioner berperan sebagai pedoman umum untuk mengingatkan peneliti agar tidak menyimpang dari tujuan penelitian. Kekhususan lain dari RRA ini adalah survei pengumpulan informasi dilakukan oleh peneliti yang multidisipliner atau peneliti yang mampu melihat masalah secara multidisipliner. Untuk mengurangi penyimpangan (bias) yang disebabkan oleh unsur subjektif peneliti maka setiap kali selesai melakukan interview dengan responden dilakukan diskusi di antara peneliti, saling tukar informasi tentang suatu masalah tertentu. Kalau ditemui perbedaan pandangan dalam suatu masalah yang disebabkan oleh adanya informasi yang keliru atau salah interpretasi maka dilakukan konfirmasi terhadap sumber informasi atau dicari informasi tambahan sehingga akan didapatkan persepsi yang sama diantara peneliti.

Data yang telah dikumpulkan dilanjutkan dengan pentabulasian sesuai dengan kebutuhan studi kemudian dilanjutkan dengan penganalisaan secara deskriptif. Di samping itu juga dilakukan analisis kuantitatif melalui pendekatan konsep pengembangan tata ruang wilayah ditinjau dari berbagai aspek, serta disesuaikan dengan keadaan fisik, ekonomi, kebijakan pemerintah, daya dukung lahan, serta sosial budaya masyarakat. Penelitian ini merupakan kajian menemukan Strategi Pengembangan Daerah $3 \mathrm{~T}$. Sasaran yang hendak dicapai adalah memacu pertumbuhan dan percepatan pembangunan di daerah tertinggal dengan sasaran peningkatan taraf hidup masyarakat desa tertinggal. Analisis data dilakukan secara deskriptif kuantitatif dan kualitatif melalui pendekatan konsep ekonomi kerakyatan dari berbagai aspek, serta disesuaikan dengan keadaan fisik, ekonomi, dan kebijakan pemerintah.

\section{Hasil dan Pembahasan}

Penelitian ini dilakukan melalui survey dengan metode perkembangan (Developmental Research). Menurut Van den Akker dan Plomp (1993) metode perkembangan (Developmental Research) adalah mendeskripsikan penelitian pengembangan berdasarkan dua tujuan yakni sebagai pengembangan prototype produk dan sebagai perumusan saran-saran metodologis untuk pendesainan dan evaluasi prototype produk tersebut. 


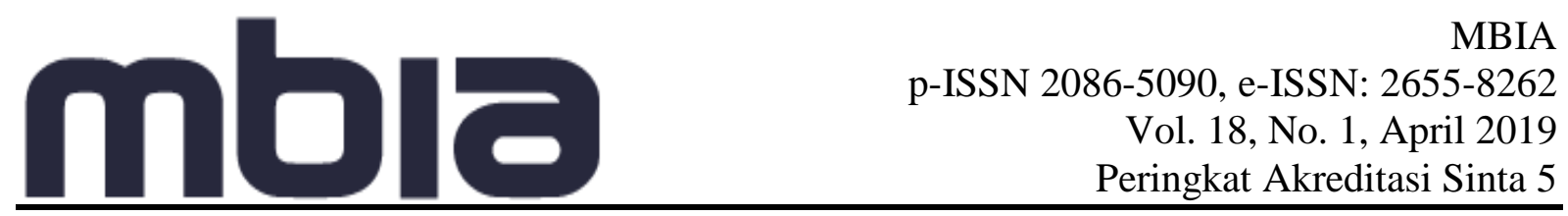

Gambar 3. Model Tahap Penelitian Developmental Research

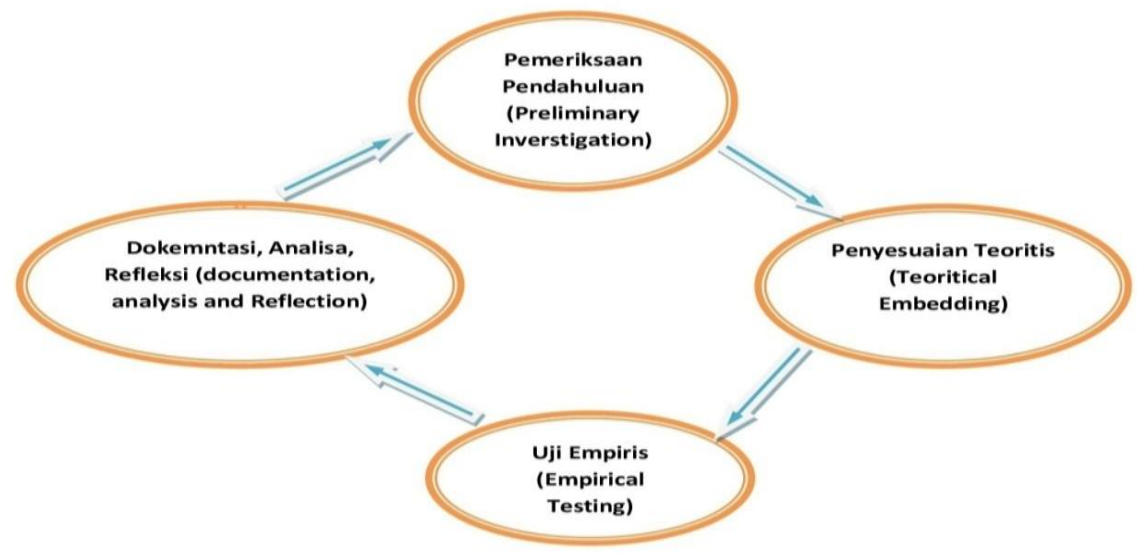

Guna mendapatkan informasi secara umum tentang keadaan daerah-daerah yang potensial untuk dikembangkan, maka penelitian ini banyak memanfaatkan data primer yang didapatkan melalui survei. Data sekunder hanya bersifat sebagai pendukung. Studi ini dilakukan di daerah Kabupaten Bengkayang provinsi Kalimantan Barat dengan pemilihan lokasi dilakukan secara cluster di daerah perbatasan.

Teknik pengumpulan data dengan metode purposive sampling. Menurut Sugiyono (2012: 122), purposive sampling adalah teknik penentuan sampel dengan pertimbangan tertentu. Metode ini digunakan dengan pertimbangan bahwa letak lokasi penelitian yang berpencaran, karakteristik masyarakat sebagai objek penelitian yang beragam, dan informasi yang diperlukan dapat diperoleh melalui kuesioner dan wawancara secara mendalam. Variabel yang diukur dalam studi ini adalah variabel yang diperlukan untuk pembangunan daerah 3T.

Penelitian ini memerlukan data primer. Untuk data primer pengumpulan data dilakukan dengan metode Rapid Rural Appraisal (RRA), yaitu suatu pendekatan partisipatif untuk mendapatkan data/informasi dan penilaian (assesment) secara umum di lapangan dalam waktu yang relatif pendek. Kelebihan pendekatan ini adalah penelitian bisa mencakup daerah yang lebih luas dalam waktu relatif singkat untuk mendapatkan informasi yang luas secara umum. Pengumpulan informasi dan data dilakukan secara fleksibel, tidak terikat secara kaku dengan kuesioner. Dalam metode RRA ini informasi yang dikumpulkan terbatas pada informasi dan yang dibutuhkan sesuai dengan tujuan penelitian, namun dilakukan dengan lebih mendalam dengan menelusuri sumber informasi sehingga didapatkan informasi yang lengkap tentang sesuatu hal. Kuesioner berperan sebagai pedoman umum untuk mengingatkan peneliti agar tidak menyimpang dari tujuan penelitian. Kekhususan lain dari RRA ini adalah survei pengumpulan informasi dilakukan oleh peneliti yang multidisipliner atau peneliti yang mampu melihat masalah secara multidisipliner. Untuk mengurangi penyimpangan (bias) yang disebabkan oleh unsur subjektif peneliti maka setiap kali selesai melakukan interview dengan responden dilakukan diskusi di antara peneliti, saling tukar informasi tentang suatu masalah tertentu. Kalau ditemui perbedaan pandangan dalam suatu masalah yang disebabkan oleh adanya informasi yang keliru atau salah interpretasi maka dilakukan konfirmasi terhadap sumber informasi atau dicari informasi tambahan sehingga akan didapatkan persepsi yang sama diantara peneliti. 
Data yang telah dikumpulkan dilanjutkan dengan pentabulasian sesuai dengan kebutuhan studi kemudian dilanjutkan dengan penganalisaan secara deskriptif. Di samping itu juga dilakukan analisis kuantitatif melalui pendekatan konsep pengembangan tata ruang wilayah ditinjau dari berbagai aspek, serta disesuaikan dengan keadaan fisik, ekonomi, kebijakan pemerintah, daya dukung lahan, serta sosial budaya masyarakat. Penelitian ini merupakan kajian menemukan Strategi Pengembangan Daerah 3 T. Sasaran yang hendak dicapai adalah memacu pertumbuhan dan percepatan pembangunan di daerah tertinggal dengan sasaran peningkatan taraf hidup masyarakat desa tertinggal. Analisis data dilakukan secara deskriptif kuantitatif dan kualitatif melalui pendekatan konsep ekonomi kerakyatan dari berbagai aspek, serta disesuaikan dengan keadaan fisik, ekonomi, dan kebijakan pemerintah.

\section{Deskripsi Wilayah}

Kabupaten Bengkayang terletak di provinsi Kalimantan Barat yang memiliki luas 5.396,4 kilometer persegi dan mempunyai 17 kecamatan. Dengan penduduk di pedesaan yang mayoritas bekerja di bidang pertanian, kehutanan, perikanan dan sebagian lagi di bidang perdagangan dan jasa. Kabupaten Bengkayang merupakan salah satu kabupaten yang terletak di sebelah utara Provinsi Kalimantan Barat. Secara administratif, batas-batas wilayah Kabupaten Bengkayang adalah sebagai berikut :

\section{Gambar.2}

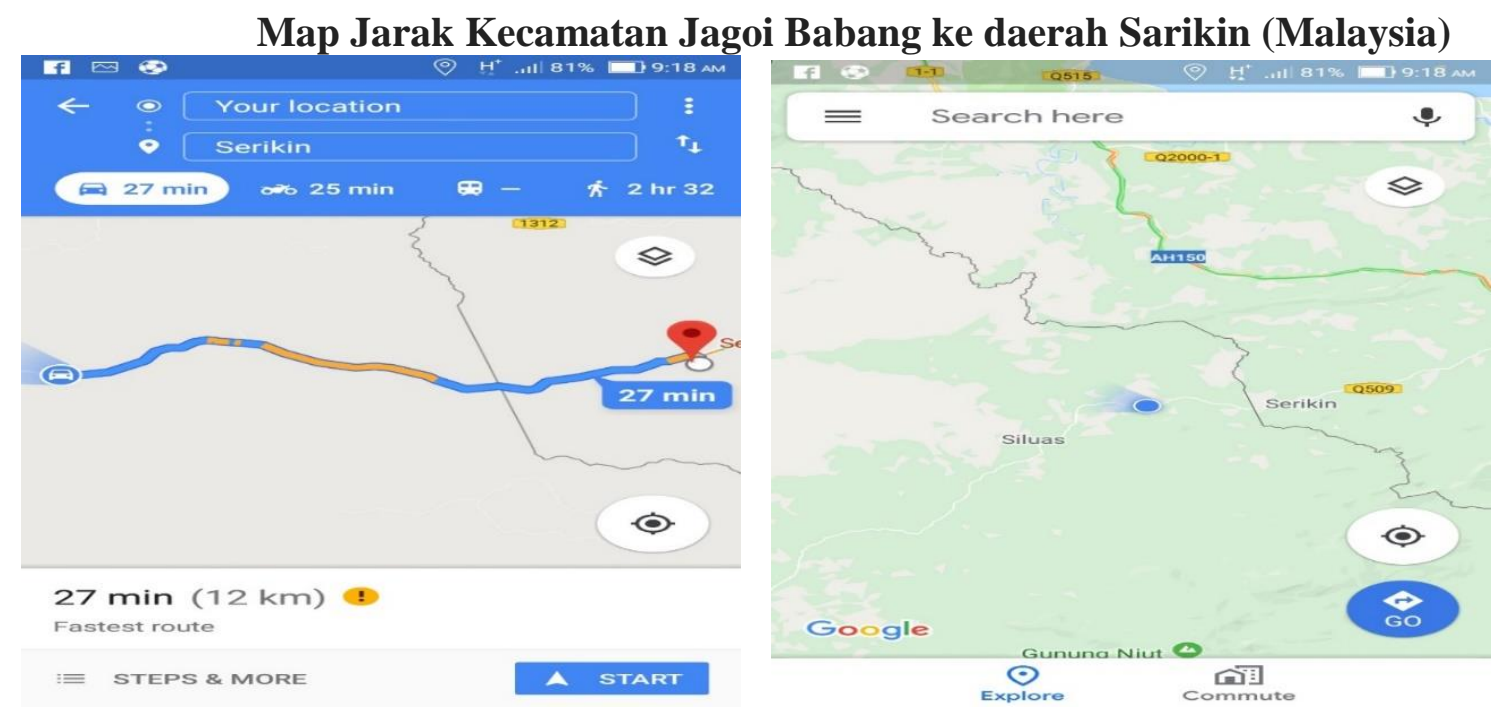

Sumber : Map Hp hasil observasi lapangan, 2018

- Utara : Serawak-Malaysia Timur

- Selatan : Kota Pontianak

- Barat : Laut Natuna dan Kota Singkawang

- Timur : Kabupaten Sanggau dan Kabupaten Landak

\section{Karakteristik Wilayah}

Ketika kita melakukan suatu penelitian yang berbentuk survei dan observasi lapangan disuatu daerah maka perlu diambil suatu kesimpulan dalam pengambilan karaktersitik daerah yang kita teliti itu, supaya membantu hasil temuan yang terjadi dalam sebuah fenomena-fenomena yang akan diungkap dalam penelitian ini.

\section{Jumlah Penduduk}


Tabel 1. Proyeksi Jumlah Penduduk Kab. Bengkayang 2013-2017

\begin{tabular}{|c|c|}
\hline Tahun & Jumlah \\
\hline 2013 & 228.771 \\
\hline 2014 & 232.873 \\
\hline 2015 & 238.610 \\
\hline 2016 & 242.788 \\
\hline 2017 & 247.084 \\
\hline
\end{tabular}

Sumber : BPS Kab. Bengkayang, 2018

Dari Tabel 1 dapat dilihat bahwa jumlah penduduk di kabupaten Bengkayang pada tahun 2013 sampai 2017 terjadi peningkatan, hal itu dapat dilihat yaitu pada tahun 2013 berjumlah 228.771 jiwa. Tahun 2014 berjumlah 232.873 jiwa. Tahun 2015 berjumlah 238.610 jiwa. Tahun 2016 berjumlah 242.788jiwa dan pada tahun 2017 berjumlah 247.084. dapat disimpulkan bahwa pertumbuhan penduduk yang ada di kabupaten bengkayang menjadi hal yang posistif untuk mampu meningkatkan daya komsumsi masyarakat terhadap suatu produk.

\section{Produk Domestik Regional Bruto}

PDRB menurut BPS didefinisikan sebagai jumlah nilai tambah yang dihasilkan oleh seluruh unit usaha dalam suatu wilayah, atau merupakan jumlah seluruh nilai barang dan jasa akhir yang dihasilkan oleh seluruhunit ekonomi di suatu wilayah. PDRB atas dasar harga berlaku menggambarkan nilai tambah barang dan jasa yang dihitung menggunakan harga pada setiap tahun, sedang PDRB atas dasar harga konstan menunjukkan nilai tambah barang dan jasa yang dihitung menggunakan harga pada tahun tertentu.

Tabel 2. Distribusi PDRB Kab. Bengkayang Atas Dasar Harga Belaku Menurut Lapangan Usaha dari tahun 2012 sampai 2016 (Jutaan Rupiah)

\begin{tabular}{|l|c|c|c|c|c|}
\hline \multicolumn{1}{|c|}{ Lapangan Usaha PDRB } & $\mathbf{2 0 1 2}$ & $\mathbf{2 0 1 3}$ & $\mathbf{2 0 1 4}$ & $\mathbf{2 0 1 5}$ & $\mathbf{2 0 1 6}$ \\
\hline Pertanian, Kehutanan, dan Perikanan & 35.23 & 34.49 & 33.15 & 31.80 & 31.61 \\
\hline $\begin{array}{l}\text { Perdagangan Besar dan Eceran; Reparasi } \\
\text { Mobil dan Sepeda Motor }\end{array}$ & 16.17 & 16.02 & 16.32 & 16.23 & 16.24 \\
\hline Industri Pengolahan & 10.25 & 10.04 & 9.87 & 9.94 & 9.89 \\
\hline Konstruksi & 9.21 & 9.81 & 10.60 & 11.22 & 11.07 \\
\hline $\begin{array}{l}\text { Administrasi Pemerintahan, Pertahanan dan } \\
\text { Jaminan Sosial Wajib }\end{array}$ & 6.26 & 6.40 & 6.45 & 6.74 & 7.05 \\
\hline
\end{tabular}

Sumber : BPS Kab.Bengkayang , 2018

Produk Domestik Regional Bruto (PDRB) kabupaten Bengkayang dari tahun 2012 sampai 2016 dapat dilihat pada tabel 2. dengan demikian bahwa sektor pertanian, kehutanan, dan perikanan sektor yang memiliki distribusi Produk Domestik Regional Bruto (PDRB) yang tinggi dengan jumlah Rp. 35.230.000.000 pada tahun 2012, pada tahun 2013 berjumlah Rp.34.490.000.000, pada tahun 2014 berjumlah Rp.33.150.000.000, pada tahun 2015 berjumlah Rp.31.800.000.000 dan pada tahun 2016 berjumlah Rp.31.610.000.000 yang mana tertinggi dari pada sektor lainnya. maka dalam hal ini dapat disimpulkan bahwa pendapatan asli daerah yang memberikan kontribusi yang baik, terutama untuk sektor tiga (3) sektor di atas. 


\section{Pendidikan}

Menurut UU No. 20 Tahun 2003, Pasal 1 Ayat 1 yaitu pengertian pendidikan adalah usaha sadar dan terencana untuk mewujudkan suasana belajar dan proses pembelajaran agar pesertadidik secara aktif mengembangkan potensi dirinya untuk memiliki kekuatan spritual keagamaan, pengendalian diri, kepribadian, kecerdasan, akhlak mulia, serta keterampilan yang diperlukan dirinya, masyarakat, bangsa, dan negara.

Tabel 3. Rata-rata Lama Sekolah Kab/Kota di Provinsi Kalimantan Barat dari tahun 2015 sampai 2016

\begin{tabular}{|l|c|c|}
\hline \multicolumn{1}{|c|}{ Kab/Kota Kalbar } & $\mathbf{2 0 1 5}$ & $\mathbf{2 0 1 6}$ \\
\hline Kubu Raya & 6.56 & 6.57 \\
\hline Kapuas Hulu & 6.42 & 6.52 \\
\hline Sambas & 6.13 & 6.42 \\
\hline Bengkayang & 5.98 & 6.08 \\
\hline Kayong Utara & 5.37 & 5.84 \\
\hline
\end{tabular}

Sumber : BPS Kab.Bengkayang, 2018

Tabel 3 merupakan penjelasan rata-rata lama sekolah masyarakat provinsi Kalimantan Barat yang terdiri dari kabupaten/kota dari tahun 2015 sampai 2016, dari tabel 4.1 dapat kita lihat bahwa kabupaten bengkayang rata-rata lama sekolah di tahun 2015 yaitu 5,98 tahun dan tahun 2016 ada peningkatan 6,08 tahun. Kabupaten Bengkayang merupakan daerah terendah nomor 2 setelah kabupaten Kayong Utara dengan rata-rata lama sekolah yang ada di provinsi Kalimantan Barat.

\section{Budaya}

Kerajinan merupakan hasil budaya bangsa yang beraneka ragam bentuk, corak, maupun fungsi yang menggambarkan citra budaya bangsa. Kerajinan adalah membuat barang pakai tidak dapat dibuat secara sembarangan saja, tidak hanya semata-mata merupakan cetusan emosi seperti halnya lahir sebuah lukisan, sebaiknya untuk barang tersebut memerlukan pertimbangan yang serius secara menyeluruh bahkan pula barang-barang tersebut akan dipasarkan. (Koko Koswara dalam Ade Eka Rosita, 2005:11) mengemukakan kerajinan anyaman adalah hasil kegiatan membuat suatu barang dengan cara menganyam bahan-bahan tertentu disertai ketekunan, ketelitian, dan kecakapan yang mempunyai nilai-nilai keindahan.

Menganyam merupakan satu kesibukan yang memberi pengalaman menyenangkan, baik dari orang tua maupun yang masih muda. Tikar merupakan jenis kerajinan tangan yang terbuat dari rotan, pandan, dan sebagainya. Bidai adalah tikar yang terbuat dari bilah-bilah rotan dan kulit kayu tarap (pantongan). Bidai ini merupakan tikar tradisional asli produk dari Kalimantan, tikar bidai ini akan memberikan suasana yang sejuk jika di tempatkan di ruang tamu, dan sangat cocok digunakan di daerah yang beriklim panas sepertiIndonesia. Selain itu, tikar bidai ini dapat digunakan layaknya seperti karpet di ruang tamu, ruang tidur, ruang makan, ruang keluarga dan lain-lain. 


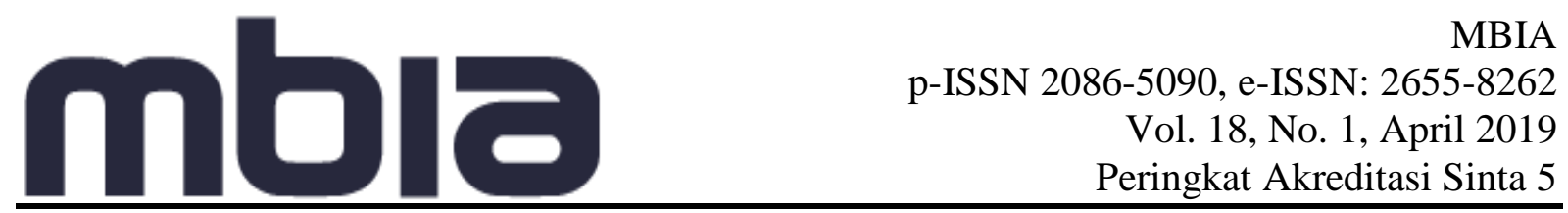

Gambar 3. Lokasi Pengayaman Tikar Bidai di Sanggau Ledo
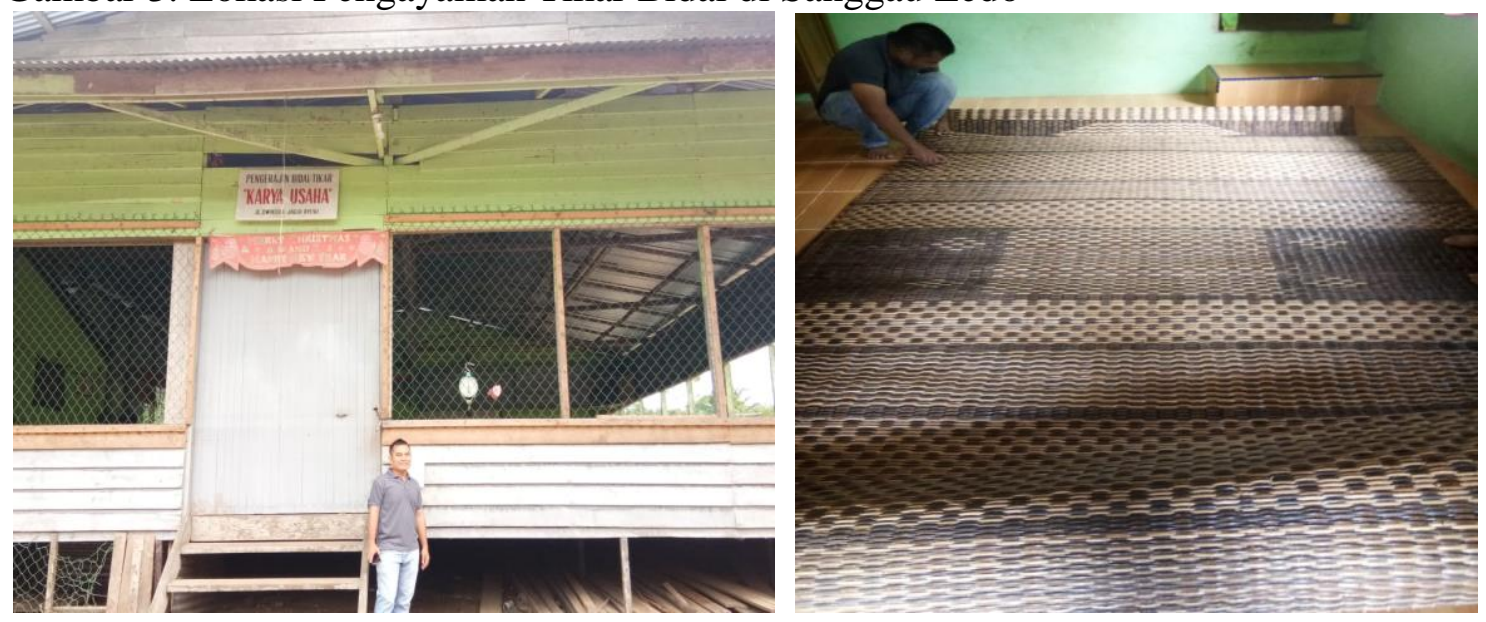

Sumber : Observasi Lapangan Peneliti, 2018

\section{Infrastruktur}

Larimer (1994) dalam Suriani (2015) menyatakan bahwa infrastruktur merupakan pondasi atau rancangan kerja yang mendasari pelayanan pokok, fasilitas dan institusi dimana bergantung pada pertumbuhan dan pembangunan dari suatu area, komunitas dan sistem. Infrastruktur meliputi variasi yang luas dari jasa, institusi dan fasilitas yang mencakup sistem transportasi dan sarana umum untuk membiayai sistem, hukum dan penegakan hukum pendidikan dan penelitian.

Gambar 4. Kondisi Infrastruktur Jalan di Kecamatan Jagoi Babang
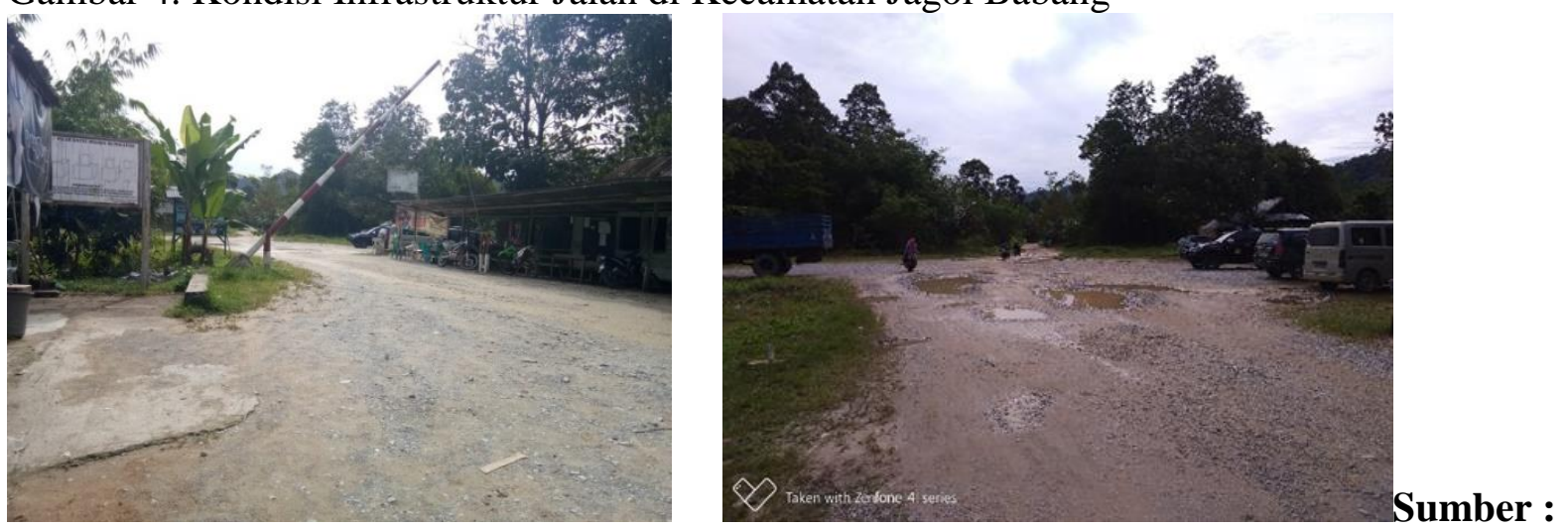

Sumber: Observasi Lapangan Peneliti, 2018

Infrastruktur jalan merupakan salah satu bagian terpenting dalam pembangunan suatu daerah, infrastruktur jalan mampu membuat laju pertumbuhan dan perkembangan masyarakat di daerah itu meningkat dan lebih maju. Jagoi babang memiliki infrastruktur jalan yang kurang baik dan layak untuk disebut jalan umum perbatasan, hal itu dapat kita lihat pada gambar 4.2 bahwa masih adanya jalan yang belum di aspal. Hal ini menjadi kendala berkembangnya daerah ini.

\section{Hasil Analisis Lapangan dan Teori}

Hasil analisis lapangan dan teori yang berkaitan dengan penelitian ini sangat dibutuhkan dalam mekombinasikan anatara teori dan praktek dilapangan, hasil analisis ini akan merangkum 
MBIA
p-ISSN 2086-5090, e-ISSN: 2655-8262
Vol. 18, No. 1, April 2019
Peringkat Akreditasi Sinta 5

semua aktivitas penelitian yang dilakukan baik secara teori dan secara fakta yang terjadi dilapangan, sehingga menghasilkan sebuah temuan yang berbentuk model yang tepat dalam pembangunan daerah $3 \mathrm{~T}$.

\section{Fakta dilapangan}

Pembangunan ekonomi daerah adalah suatu proses di mana pemerintah daerah dan masyarakatnya mengelola setiap sumberdaya yang ada dan membentuk suatu pola kemitraan antara pemerintah daerah dengan sektor swasta untuk menciptakan suatu lapangan kerja baru dan merangsang perkembangan kegiatan ekonomi (pertumbuhan ekonomi) dalam wilayah tersebut. Infrastruktur yang baik akan menghasilkan pengaruh pertumbuhan ekonomi, pertumbuhan pendidikan dan pertumbuhan teknologi di suatu daerah. Dari hasil observasi lapangan infrastruktur umum dan kesehatan masih minim di daerah perbatasan terutama kecama jagoi babang yang merupakan daerah langsung berbatasan dengan negara Malaysia.

Model pembangunan daerah yang berdasarkan pada bidang infrastruktur umum dan kesehatan sangat dibutuhkan, karena hal itu mempengaruhi kegiatan perekonomian dari daerah itu. Ketika infrastruktur di daerah itu baik maka akan ada laju pertumbuhan ekonomi yang meningkat dan pembangunan di daerah itu juga akan bertumbuh.

\section{Teori dari Sumber-sumber lain}

Dalam penelitian Lubis. D, (2008). Yang berjudul Pembangunan Daerah Tertinggal di Era Otonomi Daerah, yang mana hasil penelitiannya akan dikembangkan model-model inkubator percepatan pembangunanan kesejahteraan rakyat di daerah tertinggal seperti di Kanero Kabupaten Tolikara, Provinsi Papua :

1. Program, Percepatan Pembangunan Kawasan Produksi Daerah Tertinggal (P2KPDT), dengan sasaran kualitatif yaitu, memfasilitasi pengembangan kawasan produksi sektor pertanian, perkebunan, peternakan, perikanan, hutan tanaman industri, dan industri pengolahan di daerah tertinggal.

2. Percepatan Pembangunan Pusat Pertumbuhan Daerah Tertinggal (P4DT), dengan sasaran kualitatif yaitu, membangun pusat pertumbuhan sumber daya lokal di daerah tertinggal, dan meningkatkan sinergi pembangunan antara daerah.

3. Percepatan Pembangunan Infrastruktur Perdesaan Daerah Tertinggal (P2IPDT) dengan sasaran kualitatif yaitu, penyediaan prasarana dan sarana sosial dasar di perdesaan.

4. Percepatan Pembangunan Wilayah Perbatasan (P2WP), dengan sasaran kualitatif yaitu, mempercepat pertumbuhan ekonomi dan peningkatan kapasitas masyarakat di wilayah perbatasan.

5. Percepatan Pembangunan Daerah Tertinggal dan Khusus (P2DTK), dengan sasaran kualitatif yaitu, mempercepat pertumbuhan ekonomi dan memantapkan kehidupan sosial ekonomi, daerah-daerah tertinggal dan perbatasan.

6. Percepatan Pembangunan Sosial Ekonomi Daerah Tertinggal (P2SEDT), dengan sasaran kualitatif yaitu, penguatan kapasitas kelembagaan masyarakat dalam memanfaatkan sumberdaya pembangunan.

Penelitian yang dilakukan oleh Soares. A. et al (2015) dengan judul Peranan Pemerintah Daerah dalam Perencanaan Pembangunan Daerah. Dengan kesimpulan penelitian adalah peranan pemerintah daerah dalam perencanaan pembangunan di Distrik Manatuto yang ada pada umumnya proses perencanaan dilakukan oleh komunitas masyarakat serta pemimpin lokal, daerah penentuan strategi pembangunan daerahnya dan dirumuskan dengan 
memperhatikan kondisi dan potensi lingkungan yang dimiliki di daerah. Baik yang sudah dapat dilaksanakan maupun belum. Peranan pemerintah daerah dan komunitas masyarakat di daerah dalam pelaksanaan perencanaan pembangunan daerah itu berjalan dengan baik apabila dilihat dari segi penyusunan dokumen rencananya. Karena dokumen rencana akan menyangkut semua bidang-bidang atauaspek-aspek perencanaan yang dibutuhkan oleh masyarakat umum.

\section{Konsep Model}

Menurut Bahri (2008 :30) Konsep adalah satuan arti yang mewakili sejumlah objek yang mempunyai ciri yang sama. Orang yang memiliki konsep mampu mengadakan abstraksi terhadap objek-objek yang dihadapi, sehingga objek-objek ditempatkan dalam golongan tertentu. Objek-objek dihadirkan dalam kesadaran orang dalam bentuk representasi mental tak berperaga. Konsep juga dapat dilambangkan dalam bentuk suatu kata.

\section{Hasil Model}

Gambar 5. Kerangka Pembangunan Daerah 3T

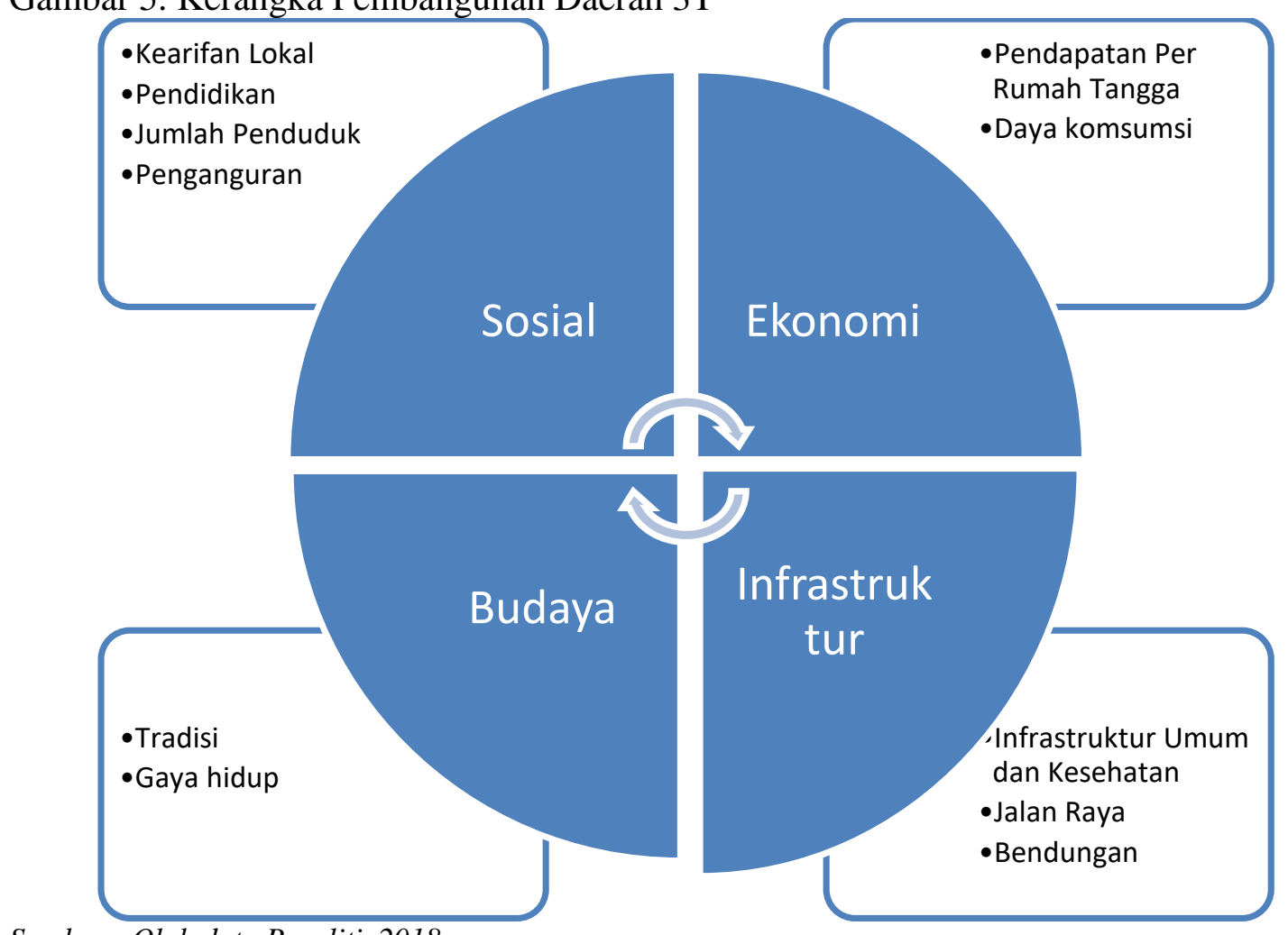

Sumber : Olah data Peneliti, 2018

Pembangunan yang berlandaskan pada 4 (empat) sektor ini sangat perlu diperhatikan, karena 4 (empat) sektor ini sangat saling keterkaitan dan mampu mengubah gaya hidup dan pola hidup masyarakat yang ada di daerah itu. Banyak penelitian yang dilakukan khususnya bagi daerahdaerah yang tertinggal atau perbatasan, menghasilkan sebuah kesimpulan bahwa pembangunan yang baik dapat dilakukan dengan memperhatikan sosial dan budaya yang ada di daerah tersebut. Dan pembangunan juga difokuskan pada pembanguan pada bidang infrastruktur umum baik itu jalan, listrik dna penyediaan air bersih. 


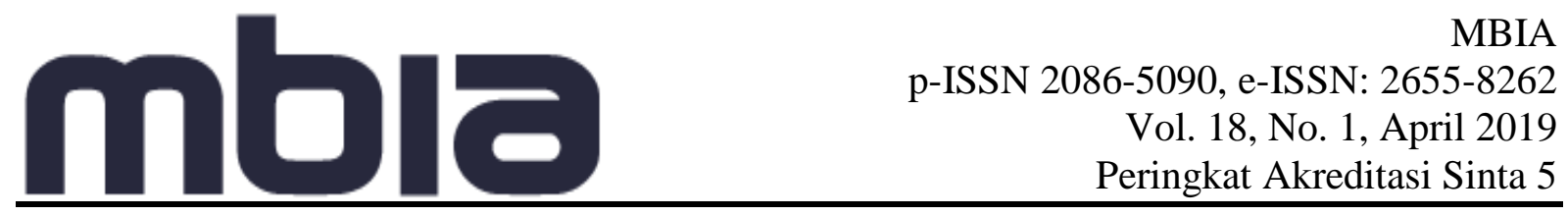

Gambar 6. Model Pembangunan Daerah 3T

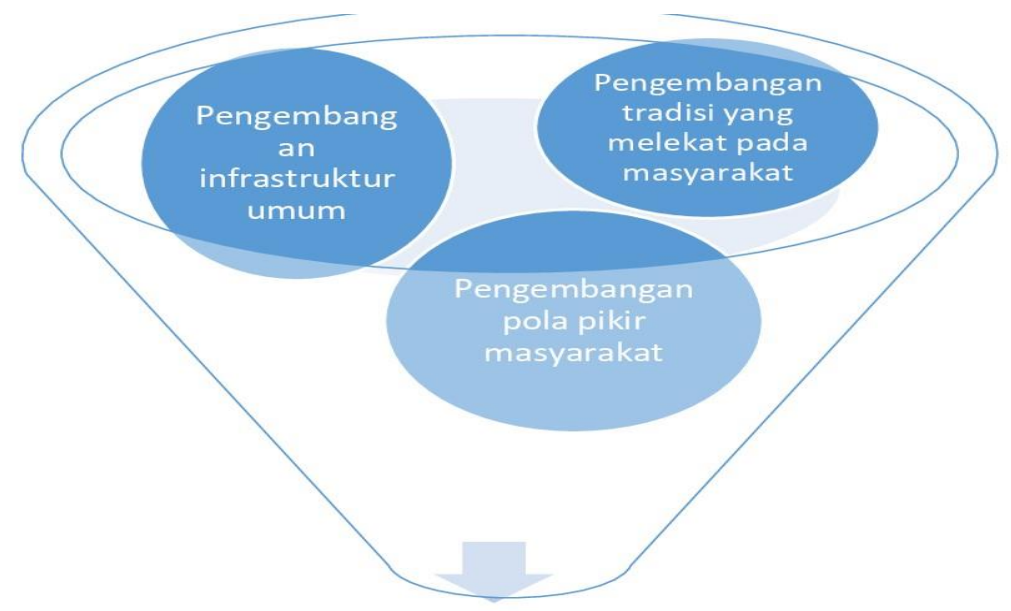

\section{Simpulan}

Penelitian ini merumuskan suatu kesimpulan model pembangunan daerah yang khususnya di daerah perbatasan, bahwa pentingnya melihat dari sisi tradisi atau kearifan lokal dan pola pikir masyarakat yang ada pada daerah tersebut. Pembangunan masyarakat atau sumber daya manusia merupakan hal yang utama setelah pembangunan infrastruktur, karena bagaimana mungkin masyrakatnya mampu menerima pembanguna dan mau mendorong pembangunan yang ada di daerahnya jika tidak ada perubahan pola pikir dari masyarakat setempat. Oleh karena itu pemerintah daerah atau pemerintah pusat harus memperhatikan sumber daya manusianya.

Pembangunan pada Pengembangan infrastruktur sangatlah penting, hal itu karena infrastruktur baik itu jalan, air bersih dan listrik merupakan salah satu roda perekonomian pada setiap daerah, terutama di daerah $3 \mathrm{~T}$, pendistribusian logistik dan pendistribusian hasil tanam, sangat membutuhkan infrastruktur yang baik terutama jalan.

Pembangunan pada pengembangan pola pikir masyarakat atau manusianya, merupakan salah satu penghambat terbesar dalam kemajuan suatu daerah, maka perlu diperhatikan bahwa perubahan pola pikir masyarakat di daerah itu sangatlah penting, hal ini perlu dilakukan pendekatan yang lembut atau tidak memaksa bahwa perubahan pembangunan di daerah itu tidak akan menganggu tradisi, adat dan kepercayaan mereka.

Pembangunan pada pengembangan tradisi yang melekat pada masyarakat tersebut, merupakan bagaimana tradisi itu mampu mengembangkan pembangunana di daerah itu dengan melibatkan dan membuat tradisi itu menjadi suatu daya Tarik untuk mendatang pengunjung atau wisata ke daerah itu.

Saran pada penelitian ini adalah perlu lebih banyak penelitian dilakukan seperti bentuk dan model pembangunan di daerah-daerah terluar, terdepan dan tertinggal agar dapat menjadi masukan bagi pihak pemerintah daerah dan pusat dalam mengalakkan pembangunan di daerahdaerah. 


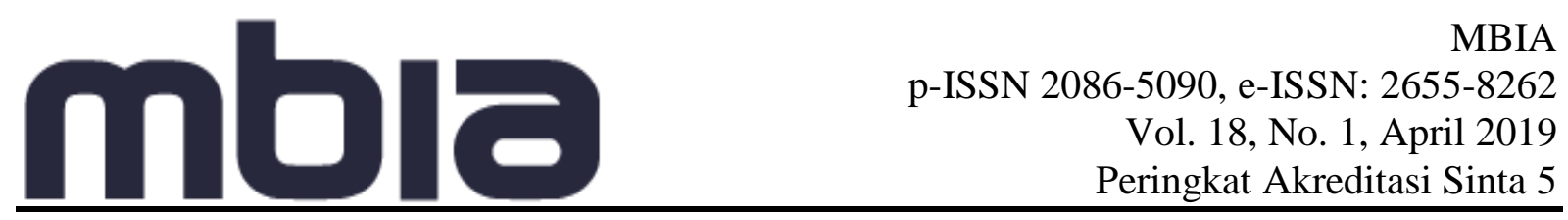

\section{Daftar Pustaka}

Ade, E, R. (2005). Kerajinan Rotan di Perusahaan Anggun Rotan Desa Manggung Wukirsari Imogiri Bantul. Yogyakarta: Program Studi Pendidikan Seni Kerajinan, FBS UNY.

Akker, V. D \& Plom. (2006). Introducing Educational Design Research. New York : Routledge

Arsyad, L. (1999). Pengantar Perencanaan dan Pembangunan Ekonomi Daerah. Yogyakarta: PT. BPFE. Yogyakarta.

Arsyad, L. (2015). Ekonomi Pembangunan Cetakan Kedua. Penerbit dan Percetakan UPP STIM YKPN. Yogyakarta

Bahri. (2008). Konsep dan Definisi Konseptual. PT. Raja Grafindo Persada: Jakarta

Bakker, A. (2004). Design research in statistics education: On symbolizing and computer tools. Desertasi Doktor pada Utrech University : Tidak diterbitkan.

Kuncoro, M. (2014). Otonomi Daerah Menuju Era Baru Pembangunan Daerah. Penerbit Erlangga. Yogyakarta

Lubis, D. (2008). Pembangunan Daerah Tertinggal di Era Otonomi Daerah. Forum Ilmiah Indonusa, 5(3), pp. $164-173$

Peraturan Presiden Republik Indonesia Nomor 131 Tahun 2015. tentang daerah tertinggal tahun. 2015-2019 Pasal 1 dan pasal 2

Soares, A. Nupratiwi, R. \& Makmur, M. (2015). Peranan Pemerintah Daerah Dalam Perencanaan Pembangunan Daerah. Jurnal Ilmu Sosial dan Ilmu Politik, 4(2).

Sugiyono. (2016). Metode Penelitian Kuantitatif, Kualitatif, dan R\&D. Cetakan ke Sembilan Belas. Bandung: Alfabeta, CV

Supriyadi, R. Antara kordinasi, Realisasi, dan Implementasi Kebijakan Pembangunan Beranda Depan. Buletin Kawasan. Direktorat Kawasan Khusus dan Daerah Tertinggal. Jakarta

Suriani, S. (2015). Pengaruh Pertumbuhan Infrastruktur Dasar Terhadap Pertumbuhan Ekonomi di Indonesia. ECOsains: Jurnal Ilmiah Ekonomi dan Pembangunan, 4(1).

Tjokrowinoto, M. (1993). Politik Pembangunan, Sebuah Konsep, Arah dan Strategi. Tiara Wacana Cetakan Kedua. Yogyakarta.

Undang-Undang Republik Indonesia nomor 20 tahun 2003 Tentang Sistem Pendidikan Nasional

\section{Copyright Disclaimer}

Copyright for this article is retained by the author(s), with first publication rights granted to the journal. 